\title{
Lessons learnt from a case of multiple myeloma
}

\author{
Raju Vaishya, Amit Kumar Agarwal, Vipul Vijay
}

Orthopaedic \& Joint

Replacement Surgery, Indraprastha Apollo Hospitals, New Delhi, India

\section{Correspondence to} Professor Raju Vaishya, raju.vaishya@gmail.com

Accepted 12 August 2015
CrossMark

\section{To cite: Vaishya $R$}

Agarwal AK, Vijay V. BMJ Case Rep Published online: [please include Day Month Year] doi:10.1136/bcr-2015211358

\section{DESCRIPTION}

A 41-year-old man presented with pain in his right arm for 6 weeks, with no systemic problems. Radiography revealed a large lytic lesion in the proximal third of the humerus (figure 1), with elevated erythrocyte sedimentation rate (ESR; $81 \mathrm{~mm}$ ) and increased uptake only in the right humerus (figure 2) on a three phase isotope technetium 99-m $(99 \mathrm{mTc})$ bone scan. Histology of the lesion indicated it to be multiple myeloma; the tumour cells were positive for CD45 and CS 138. Following core biopsy, the patient sustained a pathological fracture requiring a closed interlocking humeral nail (figure 3). A positron emission tomography CT (PET/CT) scan revealed multiple FDG (18F fluoro-2-deoxy-D-glucose) avid skeletal lesions (figure 4) and increased uptake in the right proximal humerus (figure 5). A bone marrow biopsy showed an increased (40\%) and unevenly distributed population of plasma cells (figure 6), suggestive of multiple myeloma.

A solitary lytic lesion in the diaphysis of a long bone with a high ESR could present a diagnostic dilemma as it may mimic infection, or a benign, malignant or metastatic tumour. Isotope bone scanning has limited usefulness in osteolytic lesions as it can only detect bony involvement if there is osteoblastic response. ${ }^{1} \mathrm{~A}$ PET/CT scan is a better imaging modality, as it is able to early on

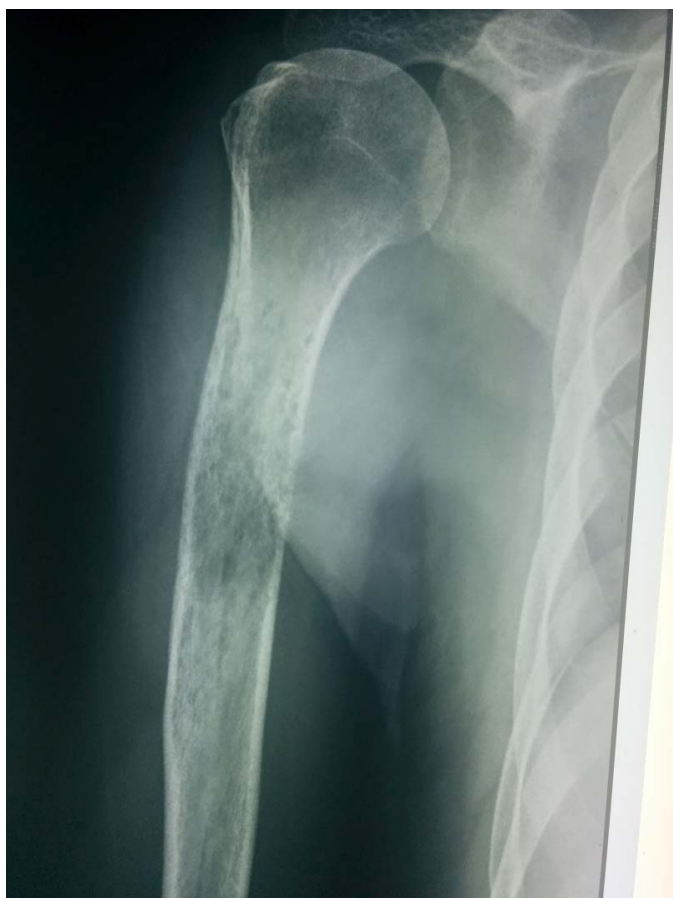

Figure 1 Anteroposterior radiograph of the humerus showing a large osteolytic lesion involving the upper third of the humerus.

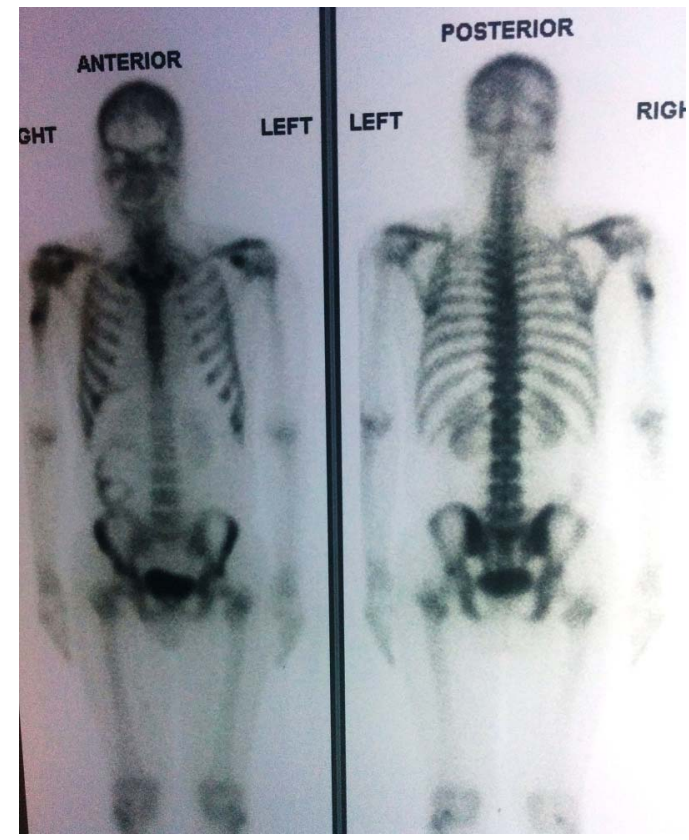

Figure 2 A radionuclide isotope bone scan showing increased uptake in the right proximal humerus and normal tracer distribution in the remaining skeleton.

detect a lesion and also can assess the extent of activeness of disease. ${ }^{2}$ Owing to the highmetabolic rate of tumour cells, there is resultant

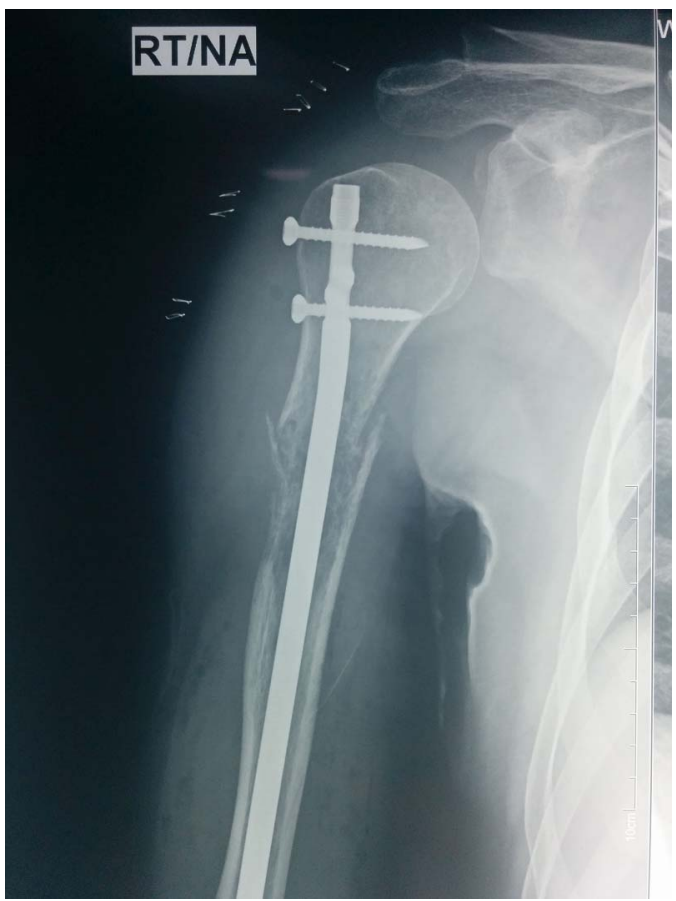

Figure 3 A pathological fracture of the humerus fixed with an interlocking humeral nail. 


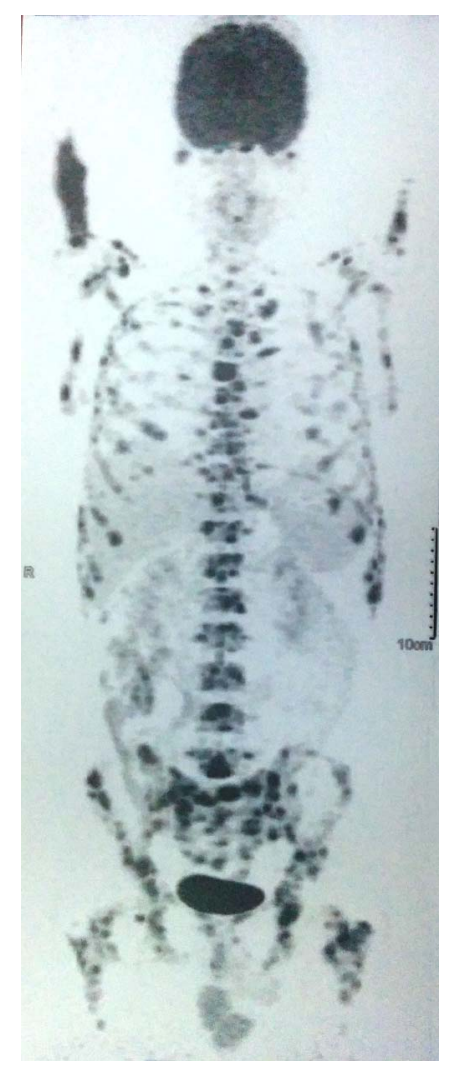

Figure 4 A positron emission tomography/CT scan showing diffuse and multiple involvement of skeleton.

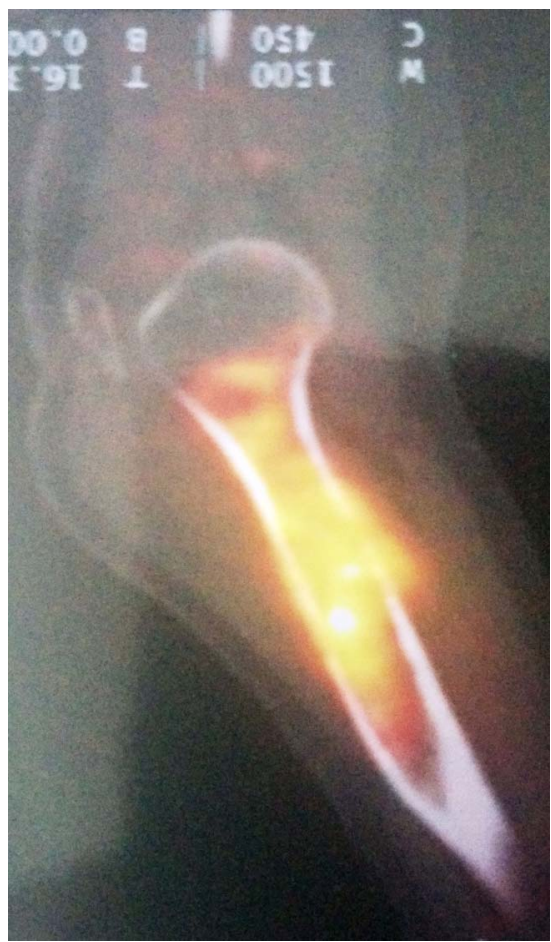

Figure 5 Increase fluoro-2-deoxy-D-glucose uptake in proximal humerus on positron emission tomography/CT scan.

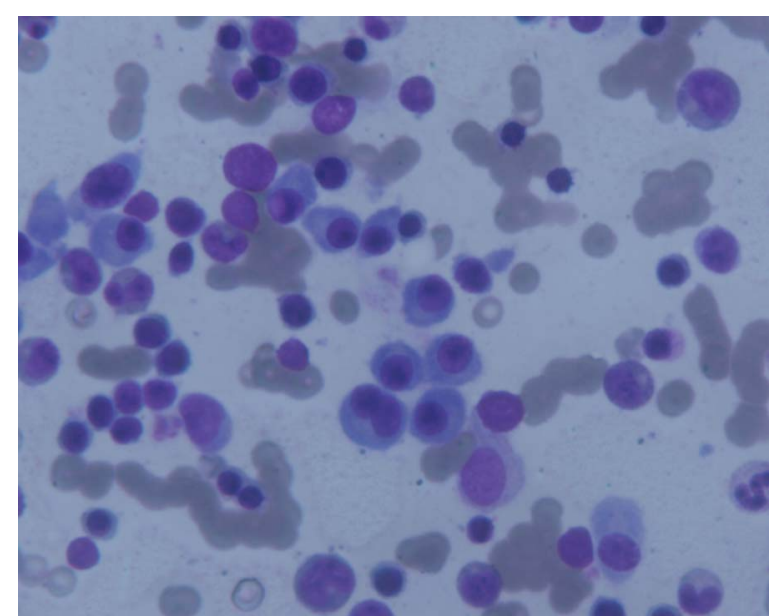

Figure 6 Bone marrow biopsy showing increased and unevenly distributed plasma cells.

higher demand for glucose, and therefore the FDG uptake is increased, differentiating them from normal cells. Large osteolytic lesions are prone to pathological fractures and should be considered for prophylactic fixation, as per Mirels' criteria. ${ }^{3}$ In this case, the score was 9 and should have been considered for prophylactic fixation, which might have prevented a pathological fracture.

\section{Learning points}

- Osteolytic lesions are best seen on positron emission tomography scan; an isotope radionuclide bone scan can miss these lesions, as there is no osteoblastic activity.

- Large lytic lesions should be prophylactically fixed with a nail or plate to avoid pathological fracture, if the Mirels' score is high (>8).

- A bone biopsy in large lytic lesions may be associated with a pathological fracture and hence must be performed carefully and only if absolutely necessary.

Competing interests None declared.

Patient consent Obtained.

Provenance and peer review Not commissioned; externally peer reviewed.

\section{REFERENCES}

1 Healy CF, Murray JG, Eustace SJ, et al. Multiple myeloma: a review of imaging features and radiological techniques. Bone Marrow Res 2011;2011: 583439.

2 Fogelman I, Cook G, Israel 0, et al. Positron emission tomography and bone metastases. Semin Nucl Med 2005:35:135-42.

3 Mirels H. Metastatic disease in long bones. A proposed system for diagnosing impending pathological fractures. Clin Orthop Relat Res 1989;249:256-64. 
Copyright 2015 BMJ Publishing Group. All rights reserved. For permission to reuse any of this content visit http://group.bmj.com/group/rights-licensing/permissions.

BMJ Case Report Fellows may re-use this article for personal use and teaching without any further permission.

Become a Fellow of BMJ Case Reports today and you can:

- Submit as many cases as you like

- Enjoy fast sympathetic peer review and rapid publication of accepted articles

- Access all the published articles

- Re-use any of the published material for personal use and teaching without further permission

For information on Institutional Fellowships contact consortiasales@bmjgroup.com

Visit casereports.bmj.com for more articles like this and to become a Fellow 